\title{
Comparative study of the serum calcium level in normal pregnancy and pre-eclamptic women in a tertiary centre in India
}

\author{
Chaitra Ramachandra ${ }^{1}$, Rekha. $\mathbf{N}^{2}$, Roopa.N.K ${ }^{3}$, Shankaregowda ${ }^{4}$, Nirupama.Y.S ${ }^{5}$ \\ ${ }^{1}$ Dr. Chaitra Ramachandra, Assistant Professor, ${ }^{2}$ Dr. Rekha, Assistant Professor, ${ }^{3}$ Dr. Roopa, Assistant Professor, \\ ${ }^{4}$ Dr. Shankaregowda, Professor, All are affiliated with Department of Obstetrics and Gynaecology, BGS Global Medical \\ College, BGS Health \& Education City, Uttarahalli Road, Kengeri, Bengaluru, Karnataka 560060, ${ }^{5}$ Dr. Nirupama.Y.S, \\ Consultant Obstetrician and gynaecologist, Shanbhag Hospital.
}

Address for Correspondence: Dr. Chaitra Ramachandra, BGS Global Hospital and Medical College, Kengeri, Bangalore, India. Email-drchaitraramachandra@gmail.com.

\begin{abstract}
Introduction: Pre-eclampsia is a significant and a common cause of maternal and foetal morbidity and mortality. Role for micronutrients supplementation in preventing preeclampsia is under extensive research. Among these, increasing calcium intake can reduce the risk of pregnancy induced hypertensive disorders. Aim: To compare the level of Serum calcium between the normal pregnancy and preeclampsia patients. Methods and Materials: This prospective double blinded case control study was conducted at Department of Obstetrics and Gynaecology, BGS Global Medical College, Bangalore from January 2015 to December 2015. A total of 120 women attending the antenatal clinic and admitted in the obstetric ward were included in the study. Among the 120 women included, 60 were with pre-eclampsia and the other 60 were normotensive patients. The pre-eclamptic patients were chosen in accordance with the National Institute for Health and Care Excellence (NICE) guidelines on hypertension. Serum calcium was measured by Colorimetric method. Data analysis was done by Graph Pad Instat (Version 3.10). Results: The study included a total of 120 patients with 60 normotensive (Group B) and 60 patients with preeclampsia patients (Group A). Majority of the patients were primigravida in the age group of 23-27 years in both the groups. The serum calcium level of group A were significantly lower in pre eclampsia women(Group A) in comparison to those of normal pregnancy (control group B ) (8.6 \pm 1.554 gm/dl Vs $9.893 \pm 0.6877 \mathrm{~g} / \mathrm{dl}: \mathrm{p}<0.0001)$. Conclusion: There was a significant reduction in serum calcium levels in preeclamptic women as compared to normal pregnant women, suggesting the role of calcium in pre-eclampsia.
\end{abstract}

Key words- Pre eclampsia, Serum Calcium, Pregnancy induced Hypertension.

\section{Introduction}

Pre-eclampsia is a significant and a common cause of maternal and fetal morbidity and mortality in a developing country like India [1]. It is a systemic disease that affects about $6-8 \%$ of all pregnancies [2]. Preeclampsia is a disorder of widespread vascular endothelial malfunction and vasospasm that occurs after 20 weeks' gestation. It is clinically defined by hypertension and proteinuria, with or without pathologic edema $[3,4]$.

Physiologically, research has linked preeclampsia to alterations in the interaction between the maternal

Manuscript received $2^{\text {nd }}$ March 2016

Reviewed: $15^{\text {th }}$ March 2016

Author Corrected: $25^{\text {th }}$ March 2016

Accepted for Publication $9^{\text {th }}$ April 2016 immune response and the placenta, placental injury, endothelial cell injury, altered vascular reactivity, oxidative stress, imbalance among vasoactive substances, decreased intravascular volume and disseminated intravascular coagulation $[5,6]$.

While the exact cause of preeclampsia remains unclear, there is strong evidence that a major cause predisposing a susceptible woman to preeclampsia is an abnormally implanted placenta [2,6]. This abnormally implanted placenta may result in poor uterine and placental perfusion, yielding a state of hypoxia and increased oxidative stress and the release of anti-angiogenic proteins along with inflammatory mediators into the maternal plasma[6]. A major consequence of this 
sequence of events is generalized endothelial dysfunction [7]. The abnormal implantation may stem from the maternal immune system's response to the placenta, specifically a lack of established immunological tolerance in pregnancy. Endothelial dysfunction results in hypertension and many of the other symptoms and complications associated with preeclampsia [7,8]. Pregnancy is associated with increased metabolic requirement [9].

Studies show that pregnant women in developing countries consume diets with lesser amounts of essential minerals and vitamins. Role for micronutrients supplementation in preventing preeclampsia is under extensive research. Among these, increasing calcium intake can reduce the risk of pregnancy induced hypertensive disorders [10-12].

Low serum calcium may cause high blood pressure by stimulating parathyroid hormone and renin release and also by inducing vasoconstriction by increasing its level in vascular smooth muscle $[10,13]$.

According to a systematic review of individual data from 12 Randomised Control Trials which included over 15,000 participants, Calcium supplementation starting in the $2^{\text {nd }}$ trimester of pregnancy reduces the risk of developing Pre Eclampsia by $64 \%$ and the risk of Maternal Mortality or severe maternal morbidity by $20 \%$ [14].

However, the roles of calcium in pregnant women are still being discussed. The aim of this study is to measure serum levels of calcium pre-eclamptic pregnancy and to compare with those in normal pregnancy.

\section{Materials and Methods}

This is a double blinded case-control study conducted at the Department of Obstetrics and Gynaecology, BGS Global Medical College, Bangalore from January 2015 to December 2015. A total of 120 women attending the antenatal clinic and admitted in the obstetric ward were included in the study. Among the 120 women included, 60 were with pre-eclampsia and the other 60 were normotensive patients. The pre-eclamptic patients were chosen in accordance with the National Institute for Health and Care Excellence (NICE) guidelines [15] on hypertension which defined Pre-eclampsia is new hypertension presenting after 20 weeks with significant proteinuria. They are classified as follow:

Mild hypertension diastolic blood pressure 90$99 \mathrm{mmHg} \&$ systolic blood pressure $140-149 \mathrm{mmHg}$, Moderate hypertension diastolic blood pressure 100 $109 \mathrm{mmHg} \&$ systolic blood pressure 150-159 mmHg, Severe hypertension diastolic blood pressure $110 \mathrm{mmHg}$ or greater \& systolic blood pressure $160 \mathrm{mmHg}$ or greater

All participants were in the third trimester of pregnancy (gestational age $>24$ weeks), primigravida or multigravida and with a single fetus. Cases and controls were matched for gestational age, parity, socioeconomic status. Informed consent was obtained from each of the subjects before recruiting in to the study.

Ethical committee clearance was obtained from the institution.

Patients with history of chronic hypertension, renal disease, cardiovascular disease, liver disease, diabetes, thyroid and other endocrine disorders, multiple gestations were excluded from the study.

A detailed family and medical history were taken. Thorough clinical examination was done in all the subjects. Systolic and diastolic blood pressure was carefully recorded. Urine analysis was done in all subjects to measure the degree of proteinuria.

Blood was taken from the ante cubital vein using a sterile needle and syringe. Blood was collected at 7 am in the morning after overnight fasting. Blood samples were allowed to clot and then centrifuged at 3000 revolutions per minute for 10 minutes. Serum calcium was measured by Colorimetric method. Results obtained were tabulated and entered in MS Excel Worksheet. Data were expressed as mean \pm SD. Independent t-test was applied for parametric variability considering $\mathrm{p}<0.05$ to be statistically significant. Data analysis was done by Graph Pad Instat (Version 3.10).

\section{Results}

A total of 120 women were included in the study, of which 60 women with pre eclampsia were included in Group A, another 60 normotensive women were included in Group B as controls. 
Table 1: Age distribution of subjects in the two groups.

\begin{tabular}{|l|l|l|}
\hline Age (in years) & $\begin{array}{l}\text { Group A (Pre Eclampsia) } \\
(\mathbf{n = 6 0})\end{array}$ & $\begin{array}{l}\text { Group B (Normal Pregnancy) } \\
(\mathbf{n = 6 0})\end{array}$ \\
\hline $18-22$ & 21 & 18 \\
\hline $23-27$ & 20 & 19 \\
\hline $28-32$ & 16 & 19 \\
\hline $33-37$ & 03 & 04 \\
\hline$>37$ & -- & -- \\
\hline Total & 60 & 60 \\
\hline
\end{tabular}

Table 1 shows the age distribution of subjects in the two groups. Majority of the subjects are in the age group of 2327 years (20 and 19 in Group A and B respectively).

Table 2: Showing the gravida distribution of study and control groups.

\begin{tabular}{|l|l|l|}
\hline Gravida & Group A (Pre Eclampsia) & Group B (Normal Pregnancy) \\
\hline Primigravida & 43 & 36 \\
\hline Multigravida & 17 & 24 \\
\hline Total & $\mathbf{6 0}$ & $\mathbf{6 0}$ \\
\hline
\end{tabular}

Majority of the subjects in the study were primigravid women as shown in Table 2

Table 3: Showing mean and standard deviation of serum calcium level in pre-eclampsia and in normal pregnancy.

\begin{tabular}{|l|l|l|l|l|l|l|}
\hline $\begin{array}{l}\text { Serum } \\
\text { calcium } \\
(\mathrm{mg} / \mathrm{dl})\end{array}$ & Group & Sample & Mean & $\begin{array}{l}\text { Standard } \\
\text { Deviation }\end{array}$ & $\begin{array}{l}\text { Standard } \\
\text { error of mean }\end{array}$ & P value \\
\cline { 2 - 6 } & $\begin{array}{l}\text { Study (Group } \\
\text { A) }\end{array}$ & 60 & 8.600 & 1.554 & 0.2564 & $<0.0001$ \\
\cline { 2 - 6 } & $\begin{array}{l}\text { Control } \\
\text { Group B) }\end{array}$ & 60 & 9.893 & 0.6877 & 0.1244 & \\
\hline
\end{tabular}

Serum calcium levels were significantly lower in study group A $(\mathrm{p}<0.0001)$ in comparison to those of control group B as shown in Table 3.

\section{Discussion}

Our study shows that women with pre eclampsia have significant lower levels of serum calcium levels when compared to women with normal blood pressure. Changes in blood pressure during preeclampsia are attributable to change in serum calcium levels which could be best explained by the level of intracellular calcium [13]

The increase in intracellular calcium or decrease in serum calcium levels leads to constriction of smooth muscle in blood vessels and subsequent increase in vascular resistance. Ionized calcium is also crucial for synthesis of Nitric Oxide and prostacyclin and hence calcium deficiency also aggravates oxidative stress. The protective effect of calcium on blood pressure can be explained by the influence of calcitrophic hormones on intracellular calcium. 1, 25-dihydro-xyvitamin D stimulates calcium influx in a variety of cells, including vascular smooth muscle cells. As a consequence, 1,25dihydroxyvitamin D exerts a repressor effect, serving to promote contraction and increase peripheral vascular resistance. Consequently, low calcium diets, which elicit a 1, 25-dihydroxyvitamin D response, would be expected to increase blood pressure [14,1618].

In a cross-sectional study from Nigeria and found extracellular calcium and magnesium reduction in patients with pre-eclampsia and eclampsia. In an another case-control study on 380 pregnant women (> 20 weeks gestation) receiving antenatal care showed serum calcium and magnesium levels are lower in pregnancy induced hypertension and pre-eclampsia than 
in normal pregnancy[19,20]. In many other studies showed serum calcium, magnesium and zinc levels to be significantly reduced in the pre-eclampsia group compared to the normal pregnant group $[6,11,20]$.

In contrary, some researchers found that serum calcium in preeclamptic group did not differ significantly from normal pregnant group [21]. This difference with our result may be attributed to the different genetic pool of the population in which the studies had been done as compared to our population and also to the different dietary habits of the population.

In a review further supported the WHO recommendation by reiterating that supplementation of calcium in pregnancy is associated with a significant reduction in the risk of pre-eclampsia. They have suggested a redirection of the research towards calcium supplementation at the community level [22].

\section{Conclusion}

Our study was conducted to compare serum calcium level in pre-eclampsia and normal pregnancy and find out any association between calcium and pre-eclampsia. There was a significant reduction in calcium levels in pre-eclamptic women as compared to normal pregnant women, suggesting the role of calcium in preeclampsia. The limitation of our study was that we did not take a detailed dietary history of the subjects.

Funding: Nil, Conflict of interest: None initiated. Permission from IRB: Yes

\section{References}

1. Sukonpan K, Phupong V. Serum calcium and serum magnesium in normal and preeclamptic pregnancy. Arch Gynecol Obstet Archives of Gynecology and Obstetrics. 2004Jul;273(1):12-6. DOI- 10.1007/s00404004-0672-4.

2. Cunningham FG, Leveno KJ, Bloom SL, Hauth JC, Gilstrap LC, Wenstrom KD. Hypertensive disorders in pregnancy. In: Cunningham FG, Leveno KJ, Bloom SL, Hauth JC, Gilstrap LC, Wenstrom KD (eds)Williams Obstetrics, 22nd edn. McGraw - Hill: New York 2005; $761-808$.

3. ACOG Practice Bulletin No. 33: Diagnosis and Management of Preeclampsia and Eclampsia. Obstetrics \& Gynecology. 2002;99(1):159-67.
4. Solomon CG, Seely EW. Preeclampsia -- searching for the cause. N Engl J Med. 2004 Feb 12; 350(7):6412. Epub 2004 Feb 5.

5. Walker JJ. Pre-eclampsia. The Lancet. 2000; 356(9237):1260-5. DOI- 10.1016/s0140-6736 (00) 02800-2.

6. Bringman J, Gibbs C, Ahokas R, Syamal B, Ramsey R, Egerman R. Differences in serum calcium and magnesium between gravidas with severe preeclampsia and normotensive controls. American Journal of Obstetrics and Gynecology. 2006;195(6). DOI10.1016/j.ajog.2006.10.519.

7. Wood AJ, Sibai BM. Treatment of Hypertension in Pregnant Women. New England Journal of Medicine N Engl J Med. 1996;335(4):257-65. DOI- 10.1056/ nejm199607253350407.

8. Serhal P, Craft I. Immune Basis For Pre-Eclampsia: Evidence From Oocyte Recipients. The Lancet. 1987;330(8561):744. DOI- 10.1016/s0140-6736 (87)91104-4.

9. Kisters K, Barenbrock M, Louwen F, Hausberg M, Rahn KH, Kosch M. Membrane, intracellular, and plasma magnesium and calcium concentrations in preeclampsia. American Journal of Hypertension. 2000Jan;13(7):765-9. DOI- 10.1016/s0895-7061(00) 00240-5.

10. Kashyap MK, Saxena SV, Khullar M, Sawhney H, Vasishta K. Role of anion gap and different electrolytes in hypertension during pregnancy (preeclampsia). Molecular and Cellular Biochemistry Mol Cell Biochem. 2006;282(1-2):157-67. DOI- 10.1007/s 11010-006-1739-2.

11. Hayashi M, Ueda Y, Hoshimoto K, Ota Y, Fukasawa I, Sumori K, et al. Changes in urinary excretion of six biochemical parameters in normotensive pregnancy and preeclampsia. American Journal of Kidney Diseases. 2002;39(2):392-400.DOI10.1053/ajkd.2002.30561.

12. Ray J, Vasishta K, Kaur S, Majumdar S, Sawhney H. Calcium metabolism in pre-eclampsia. International Journal of Gynecology \& Obstetrics. 1999;66(3):24550. DOI- 10.1016/s0020-7292(99)00096-X. 
13. Kosch M, Hausberg M, Louwen F, Barenbrock M, Rahn KH, Kisters K. Alterations of plasma calcium and intracellular and membrane calcium in erythrocytes of patients with pre-eclampsia. J Hum Hypertens Journal of Human Hypertension. 2000Oct;14(5):333-6. DOI10.1038/sj.jhh.1001006.

14. 25. Crowther CA, Hiller JE, Pridmore B, Bryce R, Duggan P, Hague WM, et al. Calcium Supplementation In Nulliparous Women For The Prevention Of Pregnancy-Induced Hypertension, Preeclampsia And Preterm Birth: An Australian Randomized Irial. Australian and New Zealand Journal of Obstetrics and Gynaecology. 1999;39(1):12. DOI-10.1111/j.1479828x.1999.tb03434.x.

15. Hypertension in pregnancy: diagnosis and management . NICE guidelines [CG107] Published date: August 2010 Last updated: January 2011.

16. Chappell LC, Seed PT, Briley A, Kelly FJ, Hunt BJ, Charnock-Jones D, et al. A longitudinal study of biochemical variables in women at risk of preeclampsia. American Journal of Obstetrics and Gynecology. 2002;187(1):127-36. DOI- 10.1067/mob.2002.122969.

17. Roberts JM, Balk JL, Bodnar LM, Belizan JM, Bergel E, Martinez A. Nutrient Involvement in Preeclampsia. J Nutr. 2003; 133(5):1684-92.
18. Deborah M. Role of nutrition in the prevention of toxemia. American Journal of Clinical Nutrition. 2000.72(1): 298-300.

19. Pijnenborg R, Anthony J, Davey DA, Rees A, Tiltman A, Vercruysse L, et al. Placental bed spiral arteries in the hypertensive disorders of pregnancy. BJOG: An International Journal of Obstetrics and Gynaecology BJOG:An international journal of O\&G. 1991;98(7):648-55. DOI- 10.1111/j.1471-0528.1991. tb13450.x.

20. Wang A, Rana S, Karumanchi SA. Preeclampsia: The Role of Angiogenic Factors in Its Pathogenesis. Physiology. 2009Jan;24(3):147-58. DOI- 10.1152/ physiol.00043.2008.

21. Ciantar E, Walker JJ. Pre-eclampsia, severe preeclampsia and hemolysis, elevated liver enzymes and low platelets syndrome: what is new? Women's Health. 2011;7(5):555-69. DOI- 10.2217/whe.11.57.

22. Belizán JM, Villar J, Gonzalez L, Campodonico L, Bergel E. Calcium Supplementation to Prevent Hypertensive Disorders of Pregnancy. New England Journal of Medicine N Engl J Med. 1991;325(20): 1399-405.DOI-10.1056/nejm 199111143252002.

\section{How to cite this article?}

Chaitra Ramachandra, Rekha. N, Roopa.N.K, Shankaregowda, Nirupama.Y.S. Comparative study of the serum calcium level in normal pregnancy and pre-eclamptic women in a tertiary centre in India. Int J Med Res Rev 2016;4(5):834838.doi: 10.17511/ijmrr.2016.i05.29. 